\title{
Some attributes of snow occurrence and snowmelt/sublimation rates in the Lesotho Highlands: environmental implications
}

\author{
Stefan Grab ${ }^{1 *}$, Jonathan Linde' and Hugo De Lemos ${ }^{1,2}$ \\ 'School of Geography, Archaeology and Environmental Studies, University of the Witwatersrand, P/Bag 3, WITS 2050, South Africa \\ ${ }^{2}$ SANSA Earth Observation Directorate, The Innovation Hub, Mark Shuttleworth Street, Pretoria, 0087, South Africa
}

\begin{abstract}
We present attributes of snow occurrence and dissipation rates (melt and sublimation) for the Lesotho Highlands, based on remotely-sensed MODIS images from 2003-2016. Multi-temporal imagery is used, with SNOMAP and NDSI algorithms applied to MODIS Rapid Response images. The spatial extent of snow loss was determined by daily repeat measurements of snow coverage, which was calculated from each filtered and trimmed MODIS SNOMAP image using the ArcGIS Spatial Analyst tool. Results indicate an average of 11.5 snowfalls per annum for the years 2003-2016; with snow longevity averaging ca. 10 days following individual snowfalls in mid-winter. Snow cover on the highest south-facing slopes persists longest during the months of June to August, in particular along the southern Drakensberg where it averages ca. 58 days during these 3 months. Mean daily melt increases by $1.6 \%$ per $1^{\circ} \mathrm{C}$ rise during the first 5 days post-snowfall, and by $3.3 \%$ per $1^{\circ} \mathrm{C}$ rise for 6 to 10 days post-snowfall. However, snowmelt rates are spatially highly variable given other factors such as wind deflation and wind-induced sublimation. The observed snow trends have important implications for biosystem functioning, regional climate and hydrology, earth surface processes, and rural livelihoods in the Lesotho Highlands.
\end{abstract}

\section{INTRODUCTION}

While southern African hydrological studies are internationally advanced in many of the sub-disciplinary components, including in particular catchment modelling (e.g. Govender and Everson, 2005; Vischel et al., 2008; Gibson et al., 2011) and groundwater studies (e.g. Levy and Xu, 2012; Schrader et al., 2014), very little work has focused on snow hydrology in the region (e.g. snowwater equivalents, snowmelt/sublimation rates, contribution to groundwater recharge, etc.). Yet, snow/ice cover and associated melt/sublimation are important hydrological phenomena for landform/scape development (Berthling and Etzelmüller, 2011), regulating freshwater supply (e.g. Schulz and de Jong, 2004; Lau et al., 2010), groundwater recharge (e.g. Wu and Xu, 2005; Dripps and Bradburg, 2010; Safeeq et al., 2013) and biosystem functioning (e.g. Hülber et al., 2010; Cortés et al., 2014). Given that several mountain and highland regions of southern Africa receive appreciable quantities of snow during at least some years, it seems appropriate to begin addressing the hydrological role and impact of snow in the African sub-continent.

Given its prevalence in high-latitude and high-altitude areas at a global scale, snow is a valuable resource in high-mountain environments, providing a considerable amount of downstream water supply as temperatures increase during spring/summer (Haq, 2008). Snowmelt may contribute up to $80 \%$ of the annual discharge of some arctic streams and rivers, with many semiarid and arid regions depending solely on snowmelt for the purposes of irrigation and power generation (Déry et al., 2005; Tahir et al., 2011). Snow affects the exchange of moisture and energy between the atmosphere and the surface, and has a significant role in the earth's radiation balance as it has the highest albedo of any natural and spatially extensive surface (Painter et al., 1998). Additionally, the presence or absence of snow cover is an important indicator of climate change

*To whom all correspondence should be addressed.

Tel: 011717 6512; e-mail: Stefan.grab@wits.ac.za

Received 27 February 2015; accepted in revised form 29 March 2017
(Haefner et al., 1997; Brown and Mote, 2009), impacts the duration of plant growing seasons (Euskirchen et al., 2006), and acts as a control on the soil thermal regime and atmospheric exchange of greenhouse gases (Dankers and De Jong, 2004). In high alpine environments, snow cover data are widely used by individuals involved with resource management, construction work, risk analysis, and the evaluation of natural hazards (Etzelmüller et al., 2001). In addition, snow cover data have valuable applications to weather prediction, hydrology, climatology, runoff prediction, reservoir management, and flood control (De Ruyter de Wildt et al., 2007; Van Der Knijff et al., 2010; Alfieri et al., 2013). Local water supply in some regions may be strongly influenced by seasonal fluctuations in the extent of snow cover, as accumulated snow acts as a natural water reservoir (Chaponnière et al., 2005; Haq, 2008). Therefore, accurate snow mapping and modelling of snowmelt/runoff are important initial steps toward ascertaining potential moisture available to local ecosystems and downstream communities, mitigating snow disasters, and reducing associated economic losses in mountainous regions.

The attributes of snow accumulation, melt/sublimation and longevity in semi-arid mountainous regions remain poorly understood. Despite the essential role of snowmelt toward supplying water to downstream regions (Haefner, et al., 1997; Chaponnière et al., 2005; Immerzeel et al., 2010), the importance of snow cover, coupled with seasonal fluctuations of its extent, has highlighted the dynamic relationship between mountain communities, their livelihoods, and environmental/ climatological controls. With the advances in modern remote sensing technology, digital mapping and snow telemetry, snowmelt/runoff has become an important field of research (DeBeer and Pomeroy, 2009), yet has not been established in southern African mountain contexts. To this end, the current paper provides a preliminary investigation into attributes of snow occurrence and dissipation rates (melt + sublimation) at the Lesotho Highlands landscape scale (see Fig. 1); here water emanating from such melt may be an important natural resource to rural communities during some seasons/years, and most 
particularly so following a relatively dry summer/autumn. It is hoped that this work will lay a foundation and stimulate further interest in southern African snow hydrological studies.

\section{REGIONAL SETTING AND PREVIOUS WORK}

Lesotho $\left(27^{\circ} 00^{\prime} \mathrm{E}-29^{\circ} 30^{\prime} \mathrm{E} ; 28^{\circ} 30^{\prime} \mathrm{S}-30^{\circ} 40^{\prime} \mathrm{S}\right)$ occupies an area of $30355 \mathrm{~km}^{2}$ and consists of the western lowlands, the topographically deep and extensive Senqunyane and Senqu River Valleys and the central and eastern highlands (Fig. 1). The highlands account for $80 \%$ of the total land area of Lesotho and host the highest mountains in southern Africa, reaching $3482 \mathrm{~m}$ amsl at Thabana Ntlenyana. The Lesotho Highlands form one of southern Africa's most important watersheds, with major water reservoir and inter-basin water transfer schemes (Snaddon et al., 1998; Zunckel, 2003). Although the various mountain ranges of Lesotho (here collectively refered to as the 'Lesotho Highlands') have a common flood-basalt origin, these vary somewhat in maximum heights reached, which, together with geographic locality, account for somewhat variable thermal and hydro-climatic characteristics between them. To this end, and to establish macro-spatial scale variability of snow duration, we identify 5 sub-regional mountain environments for Lesotho; these include the Maluti, northern Drakensberg, southern Drakensberg, Central Range, and Thaba Putsoa Range (see Fig. 1).

Annual precipitation in the Lesotho Highlands varies from ca. 800 to $1500 \mathrm{~mm} \cdot \mathrm{y}^{-1}$ (Sene et al., 1998; Nel and Sumner, 2008), but apparently exceeds evaporation (Zunckel, 2003).

Although most (80\%) contemporary precipitation occurs between October and April (Tyson, 1986; Sene et al., 1998), most snowfalls occur in mid-winter (June and July). It is estimated that between 5 and 10 contemporary snowfalls occur over the Lesotho Highlands per annum (Tyson et al., 1976; Mulder and Grab, 2002), yet the water equivalent is estimated at less than $100 \mathrm{~mm} /$ annum (Nel and Sumner, 2005). Most snowfalls in the Lesotho Highlands are a consequence of frontal perturbations in the westerlies between the months of April and October (Mulder and Grab, 2002; Grab and Nash, 2010). Snowfall events are typically associated with infrequent cut-off lows; although these

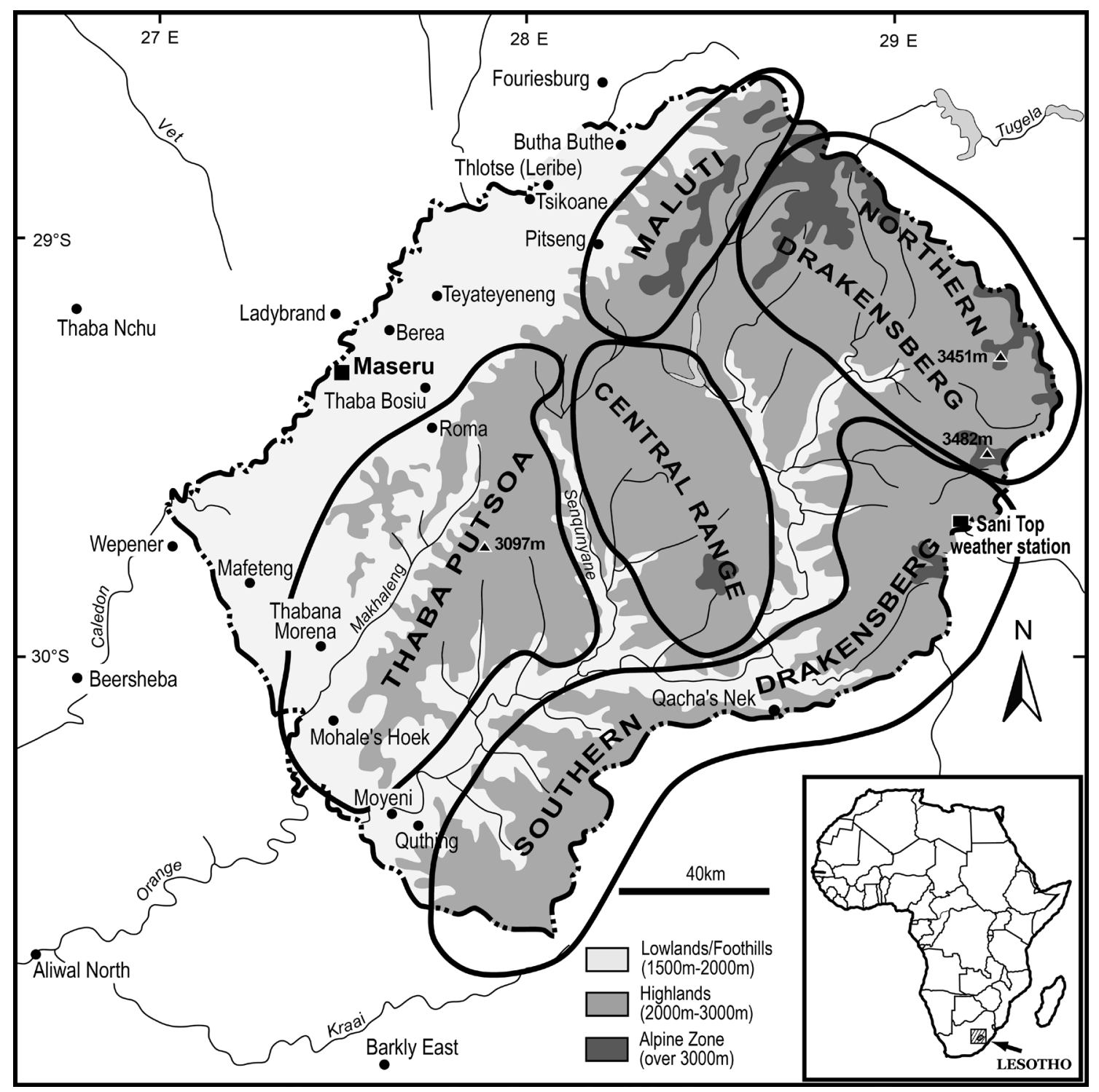

Figure 1

Topographic map of Lesotho indicating sub-regional mountain environments used for snow cover analysis through Landsat and MODIS imagery 
have a high interannual variability (Dyer, 1982), they account for ca. $80 \%$ of net contemporary snow cover (Mulder and Grab, 2009).

The earliest reports of snow in Lesotho are those from $19^{\text {th }}$ century missionaries, such as Arbouset, Cassalis and Germond (see Grab and Nash, 2010). It seems that the $19^{\text {th }}$ century received substantially heavier and more frequent snowfalls than those during more recent times, with some snowfall events lasting for up to a week, occassionaly exceeding 'two feet' in depth, and snow generally remaining in the Lesotho Highlands from May to September each year (Grab and Nash, 2010). Possibly the earliest documented snow-hydrological observation was that by Schrumpf in September 1845, at Bethesda in southwestern Lesotho: 'We forded the Makhaleng, which was again rolling its brown waters, a sign of the melting snows in our African Pyrenees, and which threatened to cut off our retreat' (Germond, 1967 p. 445).

Based on such documentary records, it is thus likely that snow typically accumulated on some mountain slopes through the cold season and rapidly melted during September, accounting for sustained stream flow and rising river levels during spring. Such a situation is unusual during the last few decades of the $20^{\text {th }}$ and early $21^{\text {st }}$ century, yet contemporary rates of snow dissipation are unknown.

Past research examining attributes of snow in Lesotho include the spatial and temporal analysis of snow distribution using remote sensing and GIS techniques (Mulder and Grab, 2002, 2009; Wunderle et al., 2016), establishing historical patterns of snow events based on documentary records (Grab and Nash, 2010), identifying associations between longlasting seasonal snow distribution with particular landform types (Grab et al., 2009), and constructing a GIS-based snow hazards map for Lesotho (Grab and Linde, 2014). Wunderle et al. (2016) provide daily time series of snow cover at various altitudes between the years 2000 and 2014, and demonstrate considerable altitudinal and inter-annual variability in snow longevity. Such past work has identified the importance of snow(melt), through its provision of ground moisture for landform development, in what is otherwise a relatively dry environment during the colder months in particular. In addition, snow in Lesotho is a frequent environmental hazard impacting the livelihoods of rural communities; hence our initiatves to improve knowledge on snow climatology/hydrology for this region. In what is likely the only snow-hydrology work yet undertaken in southern Africa, Wu and $\mathrm{Xu}$ (2005) established the potential snow impact on groundwater recharge in the Table Mountain Group of the southwestern Cape region. This study concluded that the estimated snowmelt recharge in the experimental Kommissiekraal catchment ranges between $14.1 \mathrm{~L} \cdot \mathrm{s}^{-1}$ to $15.0 \mathrm{~L} \cdot \mathrm{s}^{-1}$.

\section{DATA AND METHODS}

For ease of further discussion in this paper, we use the term 'snowmelt' to represent snow loss through: melt + sublimation + deflation. The rate of snowmelt calculated from satellite imagery is also a function of initial spatial distribution and depth (i.e. deep snow cover will slow down snowmelt rates whilst thin snow cover will disappear more rapidly under similar environmental conditions). Thus, both results and discussion on snow melt rates in this paper are based on a relationship between snow accumulation (i.e. depth) and its subsequent complete disappearance. The 'early', 'mid' and 'late' snow seasons represent the months of April-May- June, July-August and September-October-November, respectively, as suggested by Mulder and Grab (2009). Very infrequent snowfalls may occur during the December to March period, as was the case in 2000 (heavy January snowfall - snow lasted at least 7 days) and in 2012 (March snowfall). This paper specifically investigates the frequency of snowfalls and duration of maximum snow longevity across the Lesotho Highlands within temporal (monthly/ seasonal) contexts during the past 14 years (2003-2016). In addition, snowmelt rates were experimentally tested on earlier datasets available to us for the years 2003-2010.

\section{Topographic data}

A digital elevation model (DEM) with a 50-m pixel size was obtained from the South African Council for Scientific and Industrial Research (CSIR). This DEM was spatially clipped to a digital outline of Lesotho's national border to exclude unnecessary data from analysis. The 'Raster - resample' (nearest neighbour assignment) function from ArcGIS Data Management Tools was used to resample the original DEM into a raster image with $250 \mathrm{~m}$-pixel size (to match the spatial resolution of MODIS imagery). The resampled DEM was reclassified into $50 \mathrm{~m}$ vertical classes, resulting in separate images composed of 48 distinct altitude bands. ArcGIS Spatial Analyst Tools 'Surface Analysis Aspect' function was then used to extract components of aspect from the DEM.

\section{Satellite imagery}

Remotely sensed images with high and low spatial and temporal resolutions were manipulated to determine seasonal and spatial trends in snow dissipation. While many of the image processing techniques are similar to the methods used by Mulder and Grab (2002; 2009), Haq (2008) and Grab et al. (2009), new methods have been employed so as to incorporate remote sensing data of higher spatial resolution and temporal spread, as also used by Grab and Linde (2014). Multi-temporal imagery was used, with SNOMAP and NDSI algorithms (Hall et al., 1995) applied to MODIS Rapid Response $250 \mathrm{~m}$ resolution images.

MODIS Daily Snow Product imagery was preferred over the higher resolution SPOT imagery as it is freely available and has better temporal coverage over time - which is essential for measuring snowmelt rates. The MODIS products provide snow cover imagery that is already processed through a MODIS snow-product classification algorithm. Modis Rapid Response imagery with a $250 \mathrm{~m}$ spatial resolution was downloaded from the FAS_1 South Africa subset of NASA's Rapid Response System for the purpose of recording snowfalls at a temporal interval of 1 to 2 days (for the years 2003 to 2016). Composite images of band combination 3-6-7 were obtained for each observed occurrence of snow, as this makes it possible to differentiate snow and ice from clouds.

Methods used for establishing a Normalized Difference Snow Index (NDSI) follow those explained in detail by Grab and Linde (2014). However, an additional test for snow is required when using the SNOMAP snow-mapping algorithm after the NDSI has been calculated. Following the SNOMAP methodology, pixels were mapped as snow-covered if the reflectance of Band 4 was $>11 \%$ (Hall et al., 1995). The resulting SNOMAP images are Boolean, where snow-covered pixels have a value of 1 and non-snow-covered pixels have values of 0 . Finally, SNOMAP images were smoothed by means of a $3 \times 3$ median filter, and then spatially clipped to exclude pixels outside Lesotho (see also Grab and Linde, 2014). 


\section{Temperature data}

Mean daily and nocturnal air temperatures were calculated based on hourly measurements from a Davis Instruments Vantage Pro 2 weather station located at $2^{\circ} 35^{\prime} 1.50^{\prime \prime}$ S, $29^{\circ} 17^{\prime} 24.13^{\prime \prime}$ E, on the escarpment near Sani Pass at $2874 \mathrm{~m}$ amsl. (Fig. 1). Mean daytime temperatures were calculated for the period 06:00-18:00, and mean nocturnal temperatures for the period 18:00-06:00, to establish relationships between temperature and snowmelt during the winters between 2003 and 2010. Although we recognize that such temperatures are not representative across the diverse Lesotho landscape, they are used in this landscape-scale study as a relative indicator of thermal trends across the landscape, against which to compare snowmelt rates. Future studies will need to refine this to the local scale. It is also acknowledged that although air temperature is the primary control on snowmelt, other variables such as wind and vapour pressure also influence the daily variability of snowmelt rates (Zuzel and Cox, 2010), but are not possible to include for lack of available data.

\section{RESULTS}

MODIS snow cover imagery over the past 14 years (2003-2016) captured 161 snowfalls (ave. $=11.5$ snowfalls per annum) over the Lesotho Highlands region, which is considerably higher than that commonly cited (i.e. 8 events based on Tyson et al., 1976) (Fig 2; Table 1). Although the past 5 years (2012-2016) have recorded relatively high snowfall frequencies (12 to 15 events per annum), the majority of these snowfalls were very light $(<$ $2 \mathrm{~cm}$ ), and in several cases snow had melted within half a day. Conversely, the occurrence of heavier snow falls $(>10 \mathrm{~cm})$ was more frequent through to the end of the $20^{\text {th }}$ century, than post the new millennium (Grab and Linde, 2014). Most snowfalls (76) were captured during the early snow season, followed by the mid- (54) and late (31) seasons (Fig. 3), with higher snow incidences in autumn (April/May) than in spring (Sept/Oct). The months from April to September each average 1 snowfall event or more per annum, with the highest probability in June (ave. = 2.6 snowfalls per annum).

\section{Logevity of snow cover and melt rates}

As snow cover usually persists for only a few days in Lesotho, and seldom lasts longer than 10 days, snowmelt dynamics can be best represented by 2 intervals each summarizing 5 days of snow cover. Interseasonal relationships between the rates of mean daily melt and altitude are thus investigated for 1-5 days and 6-10 days following snowfalls in Lesotho. The rate of snowmelt is expressed as the percentage snow cover lost on a daily basis, from (i) the original snowfall event and (ii) snow cover remaining from the previous day.

The duration of visible snow cover on MODIS images is geographically variable, with the highest south-facing slopes of the southern Drakensberg recording, on average, ca. 76 days of snowcover, while those of the Thaba Putsoa Range only record an average of ca. 36 days of snowcover per annum (Table 1). The mean monthly duration of snow cover in areas of maximum longevity lasts between 2.5 days (April) and 17.9 days (June) for the early season, and persists longest in July (19.9 days), during the mid-season, in highest altitude regions of the northern Drakensberg. Although snow still remains on average for up to 8.1 days in parts of the Drakensberg, following

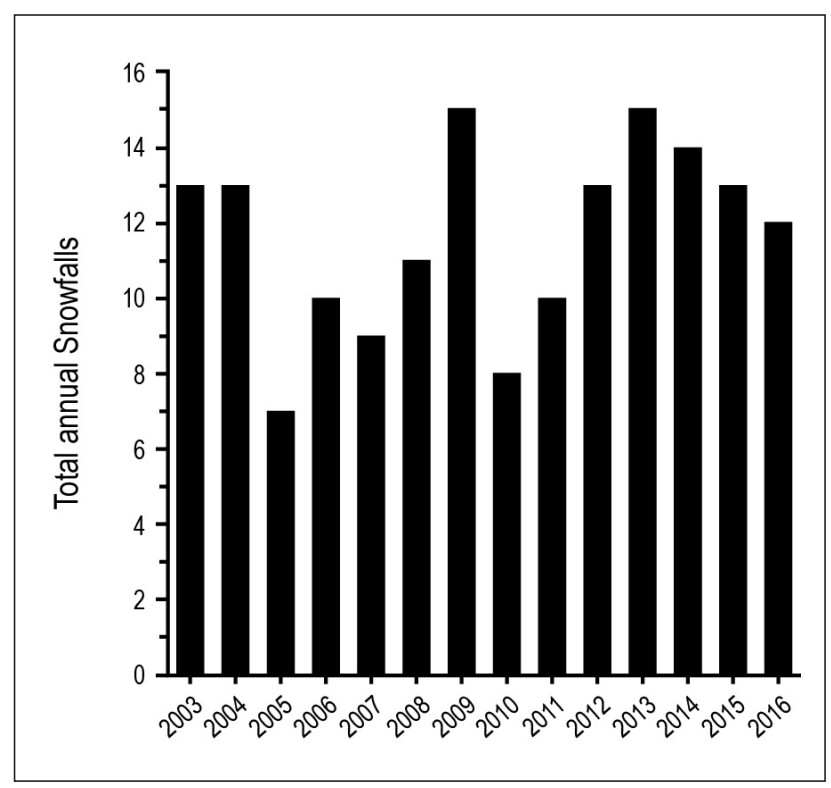

Figure 2

Total annual snowfall events in Lesotho for the years 2003-2016, captured by MODIS snow cover imagery

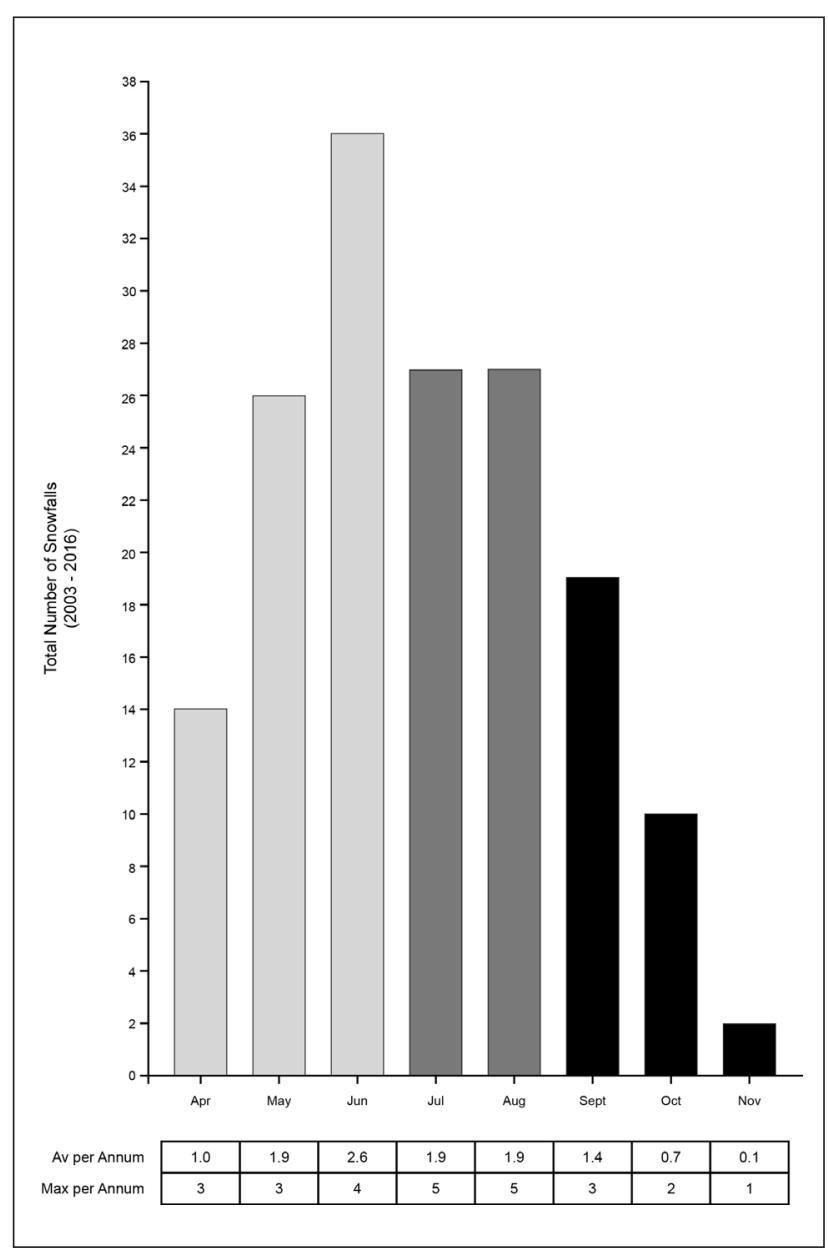

Figure 3

Total, mean and maximum number of snowfalls per month in Lesotho for the years 2003-2016, captured by MODIS snow cover imagery. April/May/ June represents the early snow season, July/August the mid snow season, and September/October/November the late snow season. 
Table 1
Sub-regional characteristics of average and maximum number of days with snow detection by MODIS snow cover imagery for the years 2003-2016

\begin{tabular}{|c|c|c|c|c|c|c|c|}
\hline \\
\hline & April & May & June & July & Aug & Sept & Annual \\
\hline \multicolumn{8}{|c|}{ Ave. snow days per annum } \\
\hline Maluti & 1.4 & 5.2 & 14.6 & 16.6 & 12.6 & 2.7 & 53.1 \\
\hline N. Drakensberg & 2.4 & 7.9 & 17.6 & 19.9 & 17.6 & 7.5 & 72.9 \\
\hline S. Drakensberg & 2.5 & 7.5 & 17.9 & 19.6 & 20.4 & 8.1 & 76.0 \\
\hline Central Range & 1.7 & 4.2 & 12.1 & 15.9 & 14.3 & 5.1 & 53.3 \\
\hline Thaba Putsoa Range & 0.7 & 2.5 & 11.0 & 10.8 & 9.3 & 1.8 & 36.1 \\
\hline \multicolumn{8}{|c|}{ Max. snow days per annum } \\
\hline Maluti & 10 & 19 & 30 & 31 & 29 & 19 & \\
\hline N. Drakensberg & 11 & 31 & 29 & 31 & 31 & 30 & \\
\hline S. Drakensberg & 11 & 31 & 30 & 31 & 31 & 30 & \\
\hline Central Range & 10 & 13 & 27 & 31 & 31 & 21 & \\
\hline Thaba Putsoa Range & 7 & 12 & 24 & 31 & 29 & 14 & \\
\hline
\end{tabular}

individual snowfalls in September, rapid spring warming results in October and November snow cover usually melting within a day. However, the areal extent of snow cover is highly variable across monthly, seasonal and inter-annual scales (see Grab and Linde, 2014), and thus the values indicated above represent maximum longevity in the highest south-facing exposures, captured by MODIS imagery. Smaller snow patches (i.e. not visible from MODIS images) in topographic niches are known to last considerably longer as is evidenced from field observations. For instance, snow patches along south-facing scarp faces were observed in the northern Drakensberg on 10 October 2016 (Fig. 4), yet these are only visible on MODIS images until 6 October.

Snow cover in Lesotho may last for only a few days before dissapearing completely; there are fewer occurrences of snow cover lasting for up to 10 days or more (32\% of occurrences) than of snow cover lasting for less than 5 days $(68 \%$ of occurrences). In terms of subaerial extent, $40-50 \%$ of snow melts within the first day, even during mid-winter, mainly due to substantial snow-loss on the warmer north-facing slope exposures. At lower altitudes ( $<1500 \mathrm{~m}$ ), $75-100 \%$ of subaerial snow extent usually melts within the first day (Fig. 5). During the early snow season, remaining snow cover at altitudes below ca. $2000 \mathrm{~m}$ melts at an average rate of $>50 \%$ per day (i.e. of cover remaining from the previous day). In contrast, at altitudes over $2500 \mathrm{~m}$, snow normally melts at a rate of less than 30\%/day. During the early season, when snow cover persisted between 6 and 10 days after a snowfall, remaining snow cover melts at an average rate of $33 \% /$ day (average for all altitudes), but decreases to $15 \%$ /day at an altitude of $3400 \mathrm{~m}$ (Fig. 4; Table 2). This rate of snowmelt is $85 \%$ /day slower than for snowmelt during the first 5 days following a snowfall. In contrast, snow cover dissipates by only $\sim 15 \% /$ day (all altitudes) between 6 and 10 days after a snowfall during the mid-snow season, thus at less than half the rate of that during the early and late ( $38 \%$ /day) snow seasons - this is largely owing to remaining snow patches located on cold, low-insolation-receiving south-facing slopes. Few instances of late season snow cover persisting for between 6 and 10 days were recorded $(n=6)$. Snow cover for late season

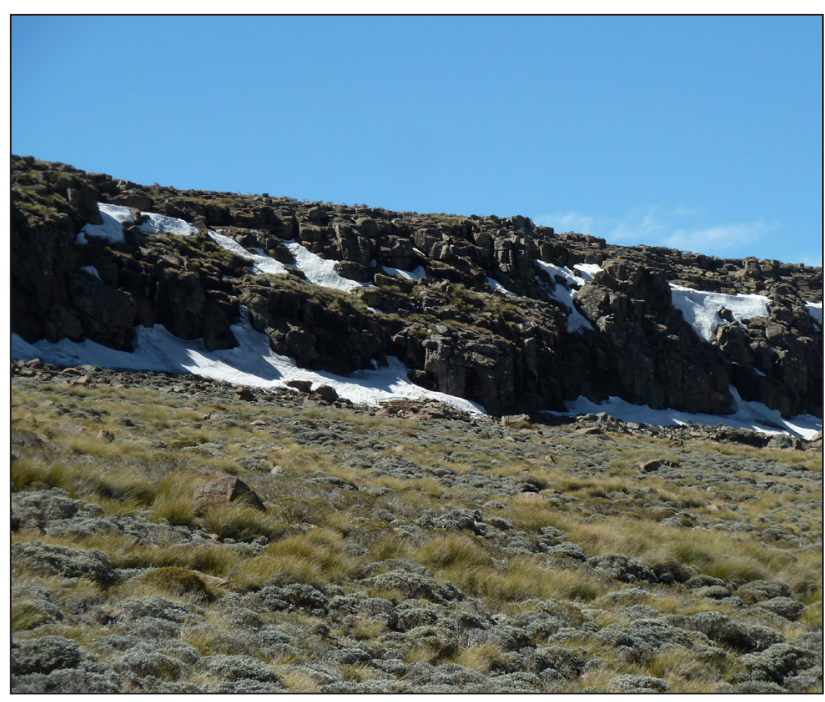

Figure 4

Visible snow patches in topographically-enhanced shaded landscape positions on 10 October 2016, northern Lesotho; yet snow is only visible on MODIS images until 6 October 2016

snowfalls is generally restricted to altitudes above $1850 \mathrm{~m}$. A notable observation is the slight spike in snowmelt rates at 3 300-3 $400 \mathrm{~m}$ amsl, during the mid- and late- season (Fig. 5). This is likely owing to high summit interfluves (i.e. flat exposed mountain tops) being exposed to wind deflation and enhanced wind-induced sublimation. Variability of snow melt rates at various altitudes is influenced by a variety of factors, such as snow pack conditions (i.e. snow physical conditions, e.g., depth, temperature, firnification) and topography (i.e. less topographic shading at lower altitude open valleys; better shading on steep upper slopes at higher altitudes; high insolation and deflation/ sublimation on high altitude summit interfluves). For instance, firnification (conversion and compaction of 'soft' snow to 'hard' ice) is best developed on high altitude (>3 $400 \mathrm{~m}$ ) south-facing slopes, and may thus account for slower melt rates. 


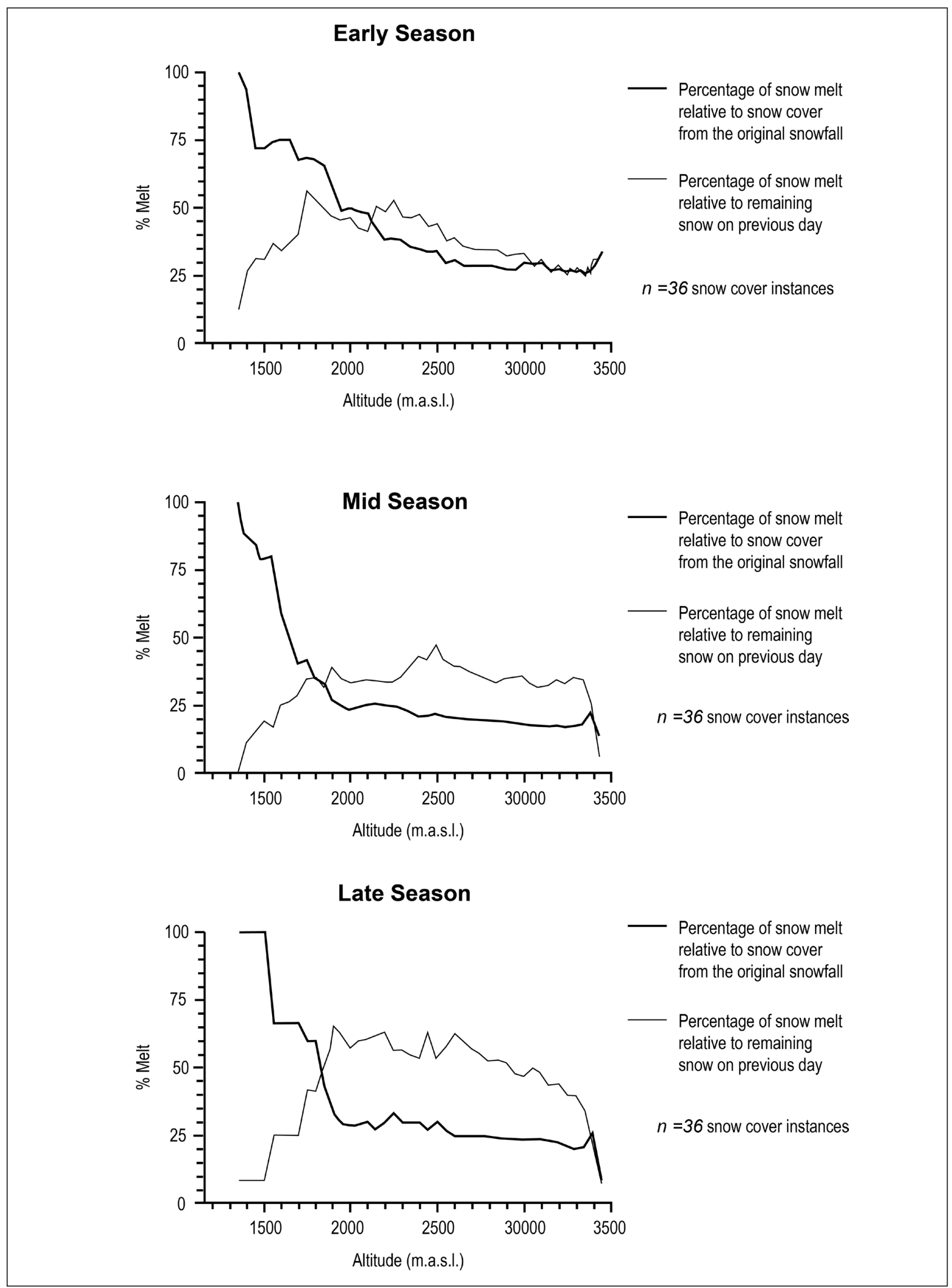

Figure 5

Percentage snow melt at various altitudes, relative to remaining snow cover from the original snowfall and relative to snow cover on the previous day (2003-2010) 


\section{TABLE 2}

Statistical summary of (A) mean daily melt of snow cover from original snowfalls and (B) mean daily melt of snow cover remaining from the previous day (2003-2010)

\begin{tabular}{|l|c|c|c|}
\hline & $\begin{array}{c}\text { Early } \\
\text { season }\end{array}$ & $\begin{array}{c}\text { Mid } \\
\text { season }\end{array}$ & $\begin{array}{c}\text { Late } \\
\text { season }\end{array}$ \\
\hline
\end{tabular}

(A) mean daily melt of snow cover from original snowfalls

\begin{tabular}{|l|l|c|c|c|}
\hline $\begin{array}{l}\text { Mean daily } \\
\text { melt }\end{array}$ & $\mathbf{1 - 5}$ days & 44.81 & 29.67 & 34.82 \\
\cline { 2 - 5 } & $\mathbf{6 - 1 0}$ days & 6.22 & 3.99 & 3.10 \\
\hline $\begin{array}{l}\text { Standard } \\
\text { Deviation }\end{array}$ & $\mathbf{1 - 5}$ days & 20.33 & 17.72 & 20.88 \\
\cline { 2 - 5 } & $\mathbf{6 - 1 0}$ days & 4.17 & 1.68 & 7.64 \\
\hline Minimum & $\mathbf{1 - 5}$ days & 26.31 & 14.35 & 8.45 \\
\cline { 2 - 5 } (\% loss/day) & $\mathbf{6 - 1 0}$ days & 0.01 & 0.13 & 0 \\
\hline Maximum & $\mathbf{1 - 5}$ days & 100 & 79.17 & 100 \\
\cline { 2 - 5 } & $\mathbf{6 - 1 0}$ days & 14.85 & 10.10 & 41.31 \\
\hline
\end{tabular}

(B) mean daily melt of snow cover remaining from the previous day

\begin{tabular}{|l|l|c|c|c|}
\hline $\begin{array}{l}\text { Mean daily } \\
\text { melt (\% loss/ } \\
\text { day) }\end{array}$ & $\mathbf{1 - 5}$ days & 37.65 & 32.01 & 46.18 \\
\hline & $\mathbf{6 - 1 0}$ days & 33.21 & 15.14 & 38.41 \\
\hline $\begin{array}{l}\text { Standard } \\
\text { Deviation }\end{array}$ & $\mathbf{1 - 5}$ days & 9.20 & 9.65 & 16.18 \\
\hline Minimum & $\mathbf{6 - 1 0}$ days & 11.24 & 5.34 & 20.76 \\
\hline (\% loss/day) & $\mathbf{1 - 5}$ days & 12.50 & 0.76 & 7.01 \\
\hline Maximum & $\mathbf{6 - 1 0}$ days & 1.96 & 1.25 & 0 \\
\hline (\% loss/day) & $\mathbf{1 - 5}$ days & 55.98 & 47.91 & 65.76 \\
\hline & $\mathbf{6 - 1 0}$ days & 45.30 & 27.84 & 71.46 \\
\hline
\end{tabular}

\section{Snow melt and air temperature}

Despite small sample sizes for late season snowfalls, the correlation of mean daily snowmelt and temperature from early-, mid- and late-season snowfall events (2003 to 2010) yields interesting statistical results (Fig. 6). Statistically significant correlations between mean rate of daily snowmelt and corresponding average day-time temperatures have coefficients of $r^{2}=0.1475$ for $1-5$ days after snowfalls $(n=54 ; P=0.0041)$, and $r^{2}=0.4276$ for $6-10$ days following snowfalls $(n=24 ; P=$ $0.0005)$. For $1-5$ days post snowfall, loss of snow cover increases at an average rate of $1.6 \%$ per $1{ }^{\circ} \mathrm{C}$ rise in air temperature at the landscape scale, compared to a $3.3 \%$ increase in snow cover lost per $1{ }^{\circ} \mathrm{C}$ rise for $6-10$ days post snowfall. The weaker relationship for 1-5 days post snowfall is likely owing to the fact that during these first few days almost all snow melts within a day on northfacing slopes due to intense direct solar radiation and heating, irrespective of day-time (shade) temperatures ranging from below $0^{\circ} \mathrm{C}$ to $>12^{\circ} \mathrm{C}$. In contrast, most snow remaining after 5 days is located on cooler (more insolation-protected and wellshadowed) south-facing slopes; hence air temperatures then have a stronger control on such remaining snow cover.

\section{DISCUSION AND CONCLUSION}

Snowfalls over the Lesotho Highlands typically occur from May to September each year, with occasional early and late events in March/April and October/November respectively. Over the last 14 years, an average of 11.5 annual snowfalls have been recorded across the mountain kingdom through MODIS satellite tracking, but, notably, the past 3 years have recorded an average of 13 snowfalls/annum. However, despite the recent high numbers of snowfalls, the majority of these were spatially limited, in some cases to a few kilometers along the Great Escarpment edge, or to an isolated summit region, such as was the case on 26/27 June 2014 when snow fell on Makoaneng (when the remainder of the Lesotho Highlands remained snow-free (see Figs 1 and 7). In addition, most of these snowfalls have been very light $(<2$ $\mathrm{cm}$ snow depth) and thus snow cover duration has been limited to less than a day or two in such instances. While $20^{\text {th }}$ century snowfalls may have occurred slightly less frequently ( $\sim 8$ annual events; Tyson et al., 1976), these were generally more widespread and heavier. It is also possible that many of the lighter and more isolated snowfalls during the $20^{\text {th }}$ century were not recorded or reported; hence the lower reported number of events by Tyson et al. (1976). Snow during the $19^{\text {th }}$ century typically lasted continuously on higher summits from May to August each year (see Grab and Nash, 2010), and usually for several weeks during most winters of the $20^{\text {th }}$ century. Such snowfall attributes, together with likely higher melt-out rates associated with climate warming during recent decades, have considerable environmental implications for the Lesotho Highlands region.

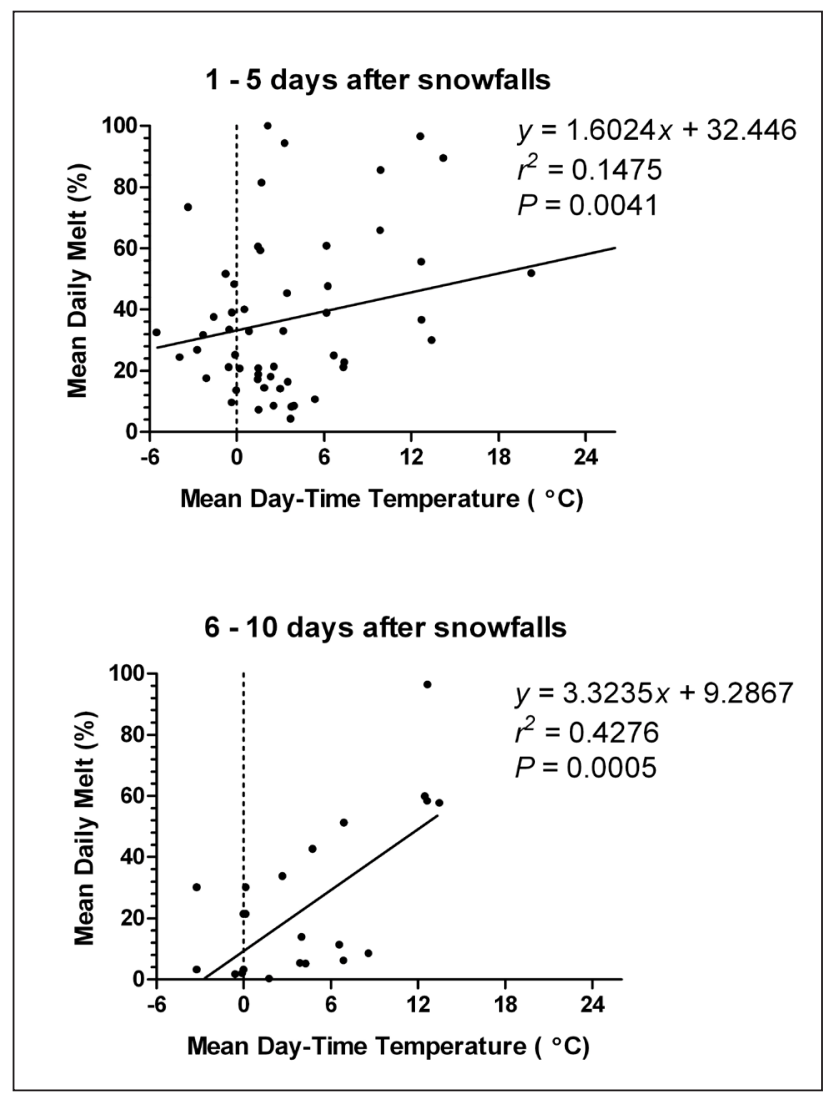

Figure 6

Correlation between mean daily snowmelt and daytime temperature for snowfalls: 2003-2010 


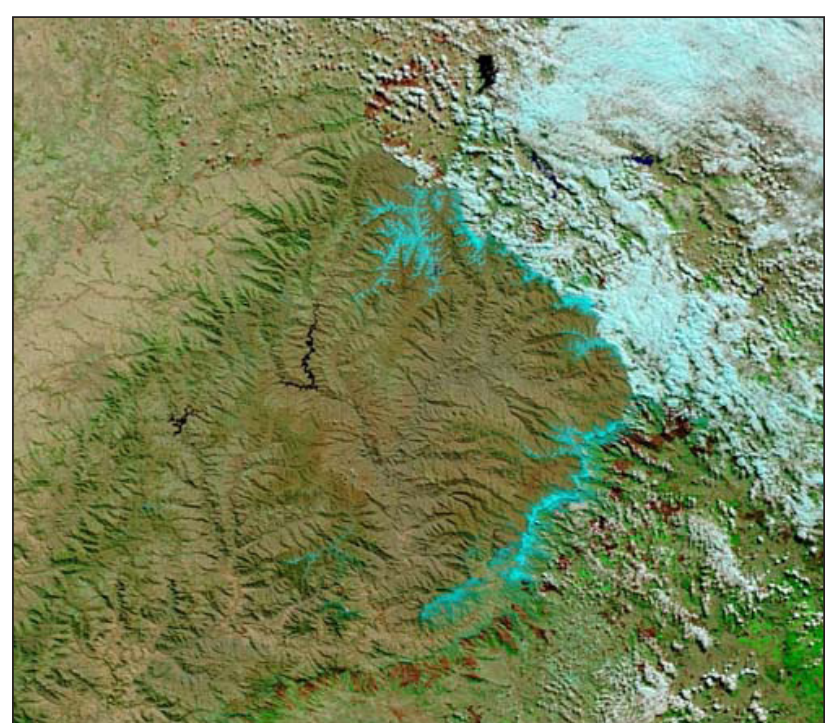

Figure 7

MODIS satellite image of 27 June 2014, indicating the strong topographic control on snow cover distribution along the Great Escarpment edge and at a few isolated high summit regions of Lesotho. Boxed area $=$ Makoaneng summit region (3 $230 \mathrm{~m}$ amsl)

\section{Geomorphic implications}

The longevity of snow cover is dependent on accumulation and heat energy, which is affected by the incident elevation, aspect and slope of the snow capture/exposure surface (Cazorzi and Fontana, 1996; Jain et al., 2009). In mountainous areas, these topographic elements are usually enhanced, and therefore snow cover is substantially variable in such environments (Hock, 2003). Altitude determines air- and surface temperatures, quantity and type of precipitation, and wind speeds. The duration of snow cover is also affected by exposure to leeward winds and topographically-controlled insolation levels (Andrés et al., 2005). Since aspect determines the level of shading and exposure to prevailing winds, it has a considerable influence on the longevity of snow. In the Lesotho Highlands/High Drakensberg, snow cover on high altitude ( $>3100 \mathrm{~m}$ amsl) south-facing slopes $\left(135-225^{\circ}\right)$ would have lasted throughout the year in topographically suitable areas during the Last Glacial Maximum (Mills et al., 2012), and for at least several months during more recent Holocene times (Grab, 1999). These slopes thus exhibited high run-off yields during past snowmelt seasons, which consequently contributed to the development of debris flows and flood deposits (see Grab, 1999). Snow cover has also played an important role in generating differential frost heave for earth hummock development (see Grab, 1997; 2005) and may also have served as a controlling mechanism for other geomorphic phenomena (see Grab et al., 2009; Grab and Mills, 2011). Given the more recent trends of ground being completely snow-free for longer periods during some winters, and with less associated melt-water supply, the dynamics of periglacial landform development and maintenance may have changed significantly since times of much deeper and longer-lasting snow cover.

\section{Snow-hydrological and climatological implications}

Snow ablation in arid to semi-arid mountains proceeds through the processes of snowmelt and sublimation (Schulz and De
Jong, 2004). This change in phase is precipitated by decreased vapour pressure, and is enhanced by increasing wind speed or solar radiation. As wind speed increases and vapour pressure decreases with altitude, high-mountain environments are susceptible to excessive water loss through sublimation (Schulz and De Jong, 2004). The rapid snow loss at summit interfluves at $~ 3250-3300 \mathrm{~m}$ amsl in Lesotho, relative to longer-lasting snow at altitudes between 3 100-3 $250 \mathrm{~m}$ amsl (see Mulder and Grab, 2009), is likely due to wind deflation and enhanced sublimation - in some instances even resulting in penitentes (thin blades of hardened snow) (S Grab, pers. obs). Given that snow albedo perturbations impact surface net solar radiation fluxes, the presence (or absence) of snow has substantial impacts on micro-/local-scale climate and soil/rock thermal regimes due to solar absorption (Qian et al., 2009; Lawrence and Slater, 2010). The recent decadal changes in Lesotho snow depth and longevity would thus accelerate micro-/local-scale climate (including ground climate) change and varialbility; this has implications for biosystem functions.

\section{Biosystem and livelihood implications}

Snow depth and longevity determine the duration of plant growing seasons and energy balances received by plants (e.g. Keller et al., 2005; Hülber et al., 2010). Thus, the shorter duration of snow cover in the Lesotho Highlands, in addition to assumed climate warming during recent decades, would have substantially enhanced the length of growing seasons and impacted on late winter/early spring water availability in the alpine belt. It is questionable, however, whether all plants would have adapted (equally) to such changes - something that future research needs to investigate.

Ice rats (Otomys sloggetti robertsi) are an endemic rodent to the Lesotho Highlands and population numbers have seemingly 'exploded' in recent years due to relatively mild winters and an absence of snow, which has improved their survival rates but has also enhanced habitat degradation and soil erosion (See: Mokotjomela et al., 2009, 2010; Marshall, 2013). According to Pillay (quoted by Marshall, 2013), 'heavy snowfalls are the sole brake on their population'. Such zoological findings are a likely consequence of the recent snowfall trends and rapid snowmelt rates discussed in this paper, which have yielded more favourable habitat conditions for ice rats and other wild fauna.

In the past, more abundant snow (and associated snow melt) would have provided a regular water supply to rural communities in the Lesotho Highlands during the drier late winter/early spring seasons. Given the more typical contemporary snow hydrological conditions, as discussed in this paper, such seasonally regulated water supply has become scarce in recent times, forcing the predominantly herder communities to adapt by, for instance, constructing makeshift water extraction cannals from springs and feeding these into fluvial channels to artificially maintain some flow during the dry late cold season. The recent decline in alpine-belt winter snowcover and population pressure in the lowlands of Lesotho has disrupted the transhumance grazing system, such that nowadays both sheep and cattle are increasingly being kept in the 'winter grazing zones', thereby depleting grazing resources and accelerating turf-degradation in the alpine belt. Possibly the most serious threat to livelihoods is that the current generation of herders is not accustomed to the dangers associated with severe blizzards and deep snow (which may remain for several weeks), and thus are not fully aware of the potential risks of overwintering their livestock in the alpine belt. Despite the recent trends of very 
light snowfalls and short longevity of remaining snow, extreme snowfall events are still possible for the foreseeable future and, therefore, caution and disaster preparedness is essential. Future work could expand on more detailed contemporary snow melt rates within various topographic and altitudinal contexts should high resolution (pereferably $<1 \mathrm{~m}$ ) daily images become available for this.

\section{ACKNOWLEDGEMENTS}

We thank the two anonymous referees who provided valuable input and helped improve this manuscript.

\section{REFERENCES}

ALFIERI L, BUREK P, DUTRA E, KRZEMINSKI B, MURARO D, THIELEN J and PAPPENBERGER F (2013) GloFAS-global ensemble streamflow forecasting and flood early warning. Hydrol. Earth Syst. Sci. 17 1161-1175. https://doi.org/10.5194/hess-17-1161-2013 ANDRÉS N, GARCIA-ROMERO A, MUÑOZ J and PALACIOS D (2005) Influence of snow distribution in vegetation cover and geomorphologic activity: Manzanares Headvalley, Sierra de Guadarrama, Spain. Geophys. Res. Abstr. 7 08551, 2005.

BERTHLING I and ETZELMÜLLER B (2011) The concept of cryoconditioning in landscape evolution. Quat Res. 75 378-384. https:// doi.org/10.1016/j.yqres.2010.12.011

BROWN RD and MOTE PW (2009) The response on Northern Hemisphere snow cover to a changing climate. J. Clim. 22 2124-2145. https://doi.org/10.1175/2008JCLI2665.1

CAZORZI F and FONTANA GD (1996) Snowmelt modelling by combining air temperature and a distributed radiation index. $J$. Hydrol. 181 169-187. https://doi.org/10.1016/0022-1694(95)02913-3

CHAPONNIÈRE A, MAISONGRANDE P, DUCHEMIN B, HANICH L, BOULET G, ESCADAFAL R and ELOUDDAT S (2005) A combined high and low spatial resolution approach for mapping snow covered areas in the Atlas mountains. Int. J. Remote Sens. 26 2755-2777. https://doi.org/10.1080/01431160500117758

CORTÉS AJ, WAEBER S, LEXER C, SEDLACEK J, WHEELER JA, VAN KLEUNEN M, BOSSDORF O, HOCH G, RIXEN C, WIPF S and KARRENBERG S (2014) Small-scale patterns in snowmelt timing affect gene flow and the distribution of genetic diversity in the alpine dwarf shrub Salix herbacea. Heredity 113 233-239. https://doi. org/10.1038/hdy.2014.19

DANKERS R and DE JONG SM (2004) Monitoring snow-cover dynamics in Northern Fennoscandia with SPOT VEGETATION images. Int. J. Remote Sens. 25 2933-2949. https://doi.org/10.1080/01 431160310001618374

DEBEER CM and POMEROY JW (2009) Modelling snow melt and snowcover depletion in a small alpine cirque. Canadian Rocky Mountains. Hydrol. Proc. 23 2584-2599.

DE RUYTER DE WILDT M, SEIZ G and GRUEN A (2007) Operational snow mapping using multitemporal Meteosat SEVIRI imagery. Remote Sens. Environ. 109 29-41. https://doi.org/10.1016/j. rse.2006.12.008

DÉRY SJ, SALOMONSON VV, STIEGLITZ M, HALL DK and APPEL I (2005) An approach to using snow areal depletion curves inferred from MODIS and its application to land surface modelling in Alaska. Hydrol. Process. 19 2755-2774. https://doi.org/10.1002/hyp.5784

DRIPPS WR and BRADBURG KR (2010) The spatial and temporal variability of groundwater recharge in a forested basin in northern Wisconsin. Hydrol. Process. 24 383-392.

DYER TGJ (1982) On the intra-seasonal variation in rainfall over the subcontinent of southern Africa. J. Climatol. 2 47-64. https://doi. org/10.1002/joc.3370020105

ETZELMÜLLER D, ØDEGÅRD RS and SOLLID JS (2001) Terrain parameters and remote sensing data in the analysis of permafrost distribution and periglacial processes: principles and examples from Southern Norway. Permafrost Periglacial Process. 12 79-92. https:// doi.org/10.1002/ppp.384
EUSKIRCHEN ES, MCGUIRE AD, KICKLIGHTER DW, ZHUANG Q, CLEIN JS, DARGAVILLE RJ, DYE DG, KIMBALL JS, MCDONALD KC, MELILLO JM, ROMANOVSKY VE and SMITH NV (2006) Importance of recent shifts in soil thermal dynamics on growing season length, productivity, and carbon sequestration in terrestrial high-altitude ecosystems. Glob. Change Biol. 12 731-750. https://doi. org/10.1111/j.1365-2486.2006.01113.x

GERMOND RC (1967) Chronicles of Basutoland: a running community on the events of the years 1830-1902 by the French protestant missionaries in southern Africa: Morija Sesuto Book Depot, Morija.

GIBSON LA, MÜNCH Z and ENGELBRECHT J (2011) Particular uncertainties encountered in using a pre-packaged SEBS model to derive evapotranspiration in a heterogeneous study area in South Africa. Hydrol. Earth Syst. Sci. 15 295-310. https://doi.org/10.5194/ hess-15-295-2011

GOVENDER M and EVERSON CS (2005) Modelling streamflow from two small South African experimental catchments using the SWAT model. Hydrol. Process. 19 683-692. https://doi.org/10.1002/hyp.5621

GRAB SW (1997) Thermal regime for a thufa and its adjoining depression, Mashai Valley, Lesotho. Permafrost Periglacial Process. 8 437-445. https://doi.org/10.1002/ (SICI) 1099-1530(199710/12)8:4<437::AID-PPP264>3.0.CO;2-O

GRAB SW (1999) Block and debris deposits in the High Drakensberg, Lesotho, Southern Africa: implications for high altitude slope processes. Geogr. Ann. 81 A 1-16. https://doi. org/10.1111/j.0435-3676.1999.00045.x

GRAB SW (2005) Earth hummocks (thúfur): new insights to their thermal characteristics and development in eastern Lesotho, southern Africa. Earth Surf. Process. Landforms 30 541-555. https:// doi.org/10.1002/esp.1150

GRAB SW and LINDE J (2014) Mapping exposure to snow in a developing African context: implications for human and livestock vulnerability in Lesotho. Nat. Hazards 71 1537-1560. https://doi. org/10.1007/s11069-013-0964-8

GRAB SW and MILLS SC (2011) Late Quaternary slope environments in the upper Sehonghong Valley, eastern Lesotho. Proc. Geol. Assoc. 122 179-185. https://doi.org/10.1016/j.pgeola.2010.02.001

GRAB SW, MULDER NA and MILLS SC (2009) Spatial associations between longest-lasting winter snow cover and cold region landforms in the High Drakensberg, southern Africa. Geogr. Ann. 91 A 1-15.

GRAB SW and NASH DJ (2010) Documentary evidence of climate variability during cold seasons in Lesotho, southern Africa, 1833-1900. Clim. Dyn. 34 473-499. https://doi.org/10.1007/ s00382-009-0598-4

HAEFNER H, SEIDEL K and EHRLER H (1997) Applications of snow cover mapping in high mountain regions. Phys. Chem. Earth 22 275278. https://doi.org/10.1016/S0079-1946(97)00143-2

HALL DK, RIGGS GA and SALOMONSON VV (1995) Development of methods for mapping global snow cover using moderate resolution imaging spectroradiometer data. Remote Sens. Enviro. 54 127-140. https://doi.org/10.1016/0034-4257(95)00137-P

HAQ M (2008) Snowmelt runoff investigation in River Swat upper basin using snowmelt runoff model, remote sensing and GIS techniques. Unpublished MSc dissertation, International Institute for GeoInformation Science and Earth Observation, The Netherlands.

HOCK R (2003) Temperature index melt modelling in mountain areas. J. Hydrol. 282 104-115. https://doi.org/10.1016/S0022-1694(03)00257-9

HÜLBER K, WINKLER M and GRABHERR G (2010) Intraseasonal climate and habitat-specific variability controls the flowering phenology of high alpine plant species. Funct. Ecol. 24 245-252. https://doi.org/10.1111/j.1365-2435.2009.01645.x

IMMERZEEL WW, VAN BEEK LPH and BIERKENS MFP (2010) Climate change will affect the Asian water towers. Science 328 1382-1385. https://doi.org/10.1126/science.1183188

JAIN SK, GOSWAMI A and SARAF AK (2009) Role of elevation and aspect in snow distribution in Western Himalaya. Water Resour. Manage. 23 71-83. https://doi.org/10.1007/s11269-008-9265-5

KELLER F, GOYETTE S and BENISTON M (2005) Sensitivity analysis of snow cover to climate change scenarios and their impact on plant habitats in alpine terrain. Climatic Change 72 299-319. https://doi. org/10.1007/s10584-005-5360-2 
LAU WKM, KIM M-K, KIM K-M and LEE W-S (2010) Enhanced surface warming and accelerated snow melt in the Himalayas and Tibetan Plateau induced by absorbing aerosols. Env. Res. Lett. 5 025204. https://doi.org/10.1088/1748-9326/5/2/025204

LAWRENCE DM and SLATER AG (2010) The contribution of snow condition trends to future ground climate. Clim. Dyn. 34 969-981. https://doi.org/10.1007/s00382-009-0537-4

LEVY J and XU Y (2012) Review: Groundwater management and groundwater/surface-water interaction in the context of South African water policy. Hydrol. J. 20 205-226. https://doi.org/10.1007/ s10040-011-0776-4

MARSHALL M (2013) Zoologger: The rat with two faces. New Scientist, 25 April 2013.

MILLS SC, GRAB SW, REA BR, CARR SC and FARROW A (2012) Shifting westerlies and precipitation patterns during the Late Pleistocene in southern Africa determined using glacier reconstruction and mass balance modeling. Q. Sci. Rev. 55 145-159. https://doi.org/10.1016/j.quascirev.2012.08.012

MOKOTJOMELA T, SCHWAIBOLD U and PILLAY N (2009) Does the ice rat Otomys sloggetti robertsi contribute to habitat change in Lesotho? Acta Oecol. 35 437-443. https://doi.org/10.1016/j. actao.2009.01.004

MOKOTJOMELA T, SCHWAIBOLD U and PILLAY N (2010) Population survey of the ice rat Otomys sloggetti robertsi in the Lesotho Drakensberg. Afr. Zool. 45 225-232. https://doi. org/10.3377/004.045.0201

MULDER N and GRAB SW (2002) Remote sensing for snow cover analysis along the Drakensberg escarpment. S. Afr. J. Sci. 98 213-216.

MULDER N and GRAB SW (2009) Contemporary spatio-temporal patterns of snow cover over the Drakensberg. S. Afr. J. Sci. 105 228-233.

NEL W and SUMNER PD (2005) First rainfall data from the KZN Drakensberg escarpment edge (2002 and 2003). Water SA 31 399-402. https://doi.org/10.1111/j.1468-0459.2008.00337.x

NEL W and SUMNER PD (2008) Rainfall and temperature attributes on the Lesotho-Drakensberg escarpment edge, southern Africa. Geogr. Ann. 90A 97-108.

PAINTER TH, ROBERTS DA, GREEN RO and DOZIER J (1998) The effect of grain size on spectral mixture analysis of snow-covered area from AVIRIS data. Remote. Sens. Enviro. 65 320-332. https://doi. org/10.1016/S0034-4257(98)00041-8

QIAN Y, GUSTAFSON WI, LEUNG LR and GHAN SJ (2009) Effects of soot-induced snow albedo change on snow pack and hydrological cycle in western United States based on weather research and forecasting chemistry and regional climate simulations. J. Geophys. Res. 114 D03108. https://doi.org/10.1029/2008JD011039

SAFEEQ M, GRANT GE, LEWIS SL and TAGUE CL (2013) Coupling snowpack and groundwater dynamics to interpret historical streamflow trends in the western United States. Hydrol. Process. 27 655-668. https://doi.org/10.1002/hyp.9628

SCHRADER A, ERASMUS E and WINDE F (2014) Determining hydraulic parameters of a karst aquifer using unique historical data from large-scale dewatering by deep level mining- a case study from South Africa. Water SA 40 555-570. https://doi.org/10.4314/wsa. v40i3.20

SCHULZ O and DE JONG C (2004) Snowmelt and sublimation: field experiments and modelling in the High Atlas Mountains of Morocco. Hydrol. Earth Syst. Sci. 8 1076-1089. https://doi.org/10.5194/ hess-8-1076-2004

SENE KJ, JONES DA, MEIGH JR and FARQUHARSON FAK (1998) Rainfall and flow variations in the Lesotho Highlands. Int. J. Clim. 18 329-345. https://doi.org/10.1002/ (SICI) 1097-0088(19980315)18:3<329::AID-JOC251>3.0.CO;2-5

SNADDON CD, WISHART MJ and DAVIES BR (1998) Some implications of inter-basin water transfers for river ecosystem functioning and water resources management in southern Africa. Aquat. Ecosyst. Health Manage. 1 159-182.

TAHIR AA, CHEVALLIER P, ARNAUD Y, NEPPEL L and AHMAD B (2011) Modelling snowmelt-runoff under climate scenarios in the Hunza River basin, Karakoram Range, northern Pakistan. J. Hydrol. 409 104-117. https://doi.org/10.1016/j.jhydrol.2011.08.035

TYSON PD, PRESTON-WHYTE RA and SCHULZE RE (1976) The Climate of the Drakensberg. Natal Town and Regional Planning Commission, Pietermaritzburg.

TYSON PD (1986) Climatic Change and Variability in Southern Africa. Oxford University Press, Cape Town.

VAN DER KNIJFF JM, YOUNIS J and DE ROO APJ (2010) LISFLOOD: a GIS-based distribution model for river basin scale water balance and flood simulation. Int. J. Geogr. Inf. Sci. 24 189-212. https://doi. org/10.1080/13658810802549154

VISCHEL T, PEGRAM G, SCOTT SINCLAIR S and PARAK M (2008) Implementation of the TOPKAPI model in South Africa: initial results from the Liebenbergsvlei catchment. Water SA 34 331-342.

WU Y and XU Y (2005) Snow impact on groundwater recharge in Table Mountain Group aquifer systems with a case study of the Kommissiekraal River catchment, South Africa. Water SA $31275-282$.

WUNDERLE S, GROSS T and HÜSLER F (2016) Snow extent variability in Lesotho derived from MODIS data (2000-2014). Remote Sens. 8 448. https://doi.org/10.3390/rs8060448

ZUNCKEL K (2003) Managing and conserving southern African grasslands with high endemism. Mt. Res. Dev. 23 113-118. https:// doi.org/10.1659/0276-4741(2003)023[0113:MACSAG]2.0.CO;2

ZUZEL JF and COX LM (2010) Relative importance of meteorological vatiables in snowmelt. Water Resour. Res. 11 174-176. 